\title{
ENEMIGOS UNOS DE OTROS (Notas de Antropología coránica)
}

\author{
Por \\ EMILIO TORNERO
}

\begin{abstract}
«Pero el Demonio les hizo caer, perdiéndolo, y les sacó del estado en que estaban. Y dijimos: "iDescended! Seréis enemigos unos de otros..." "(1).
\end{abstract}

«No es necesario probar por oscuros fragmentos de Heráclito que el ser se revela como guerra al pensamiento filosófico, que la guerra no sólo lo afecta como el hecho más patente, sino como la patencia misma - o la verdad-de lo real. En ella, la realidad desgarra las palabras y las imágenes que la disimulan para imponerse en su desnudez y dureza..., la guerra se presenta como la experiencia pura del ser puro» (2).

Tampoco es necesario insistir en aquellos bien conocidos adagios, sobre los que en buena parte se ha constituido la cultura de Occidente, del «homo homini lupus» o del «status belli omnium contra omnes».

La exégesis bíblica ha puesto de relieve últimamente que el Génesis ha sido escrito como una prehistoria del Éxodo a fin de explicar el origen del pecado. «Pero se hace necesario precisar que el pecado cuyo origen se trata de explicar es el pecado de Caín» (3). Von Rad destaca que la historia de Caín y Abel es el retrato de la humanidad extraparadisiaca, «histórica» (4). La narración de Adán «es únicamente para que se sepa que el hombre no era así desde el principio, que Dios no lo creó

(1) Corán 2,36. Cfr.: 7,24 y 20, 123. Doy la traducción de J. Cortés, El Corán, Madrid, Editora Nacional, 1980.

(2) E. Levinas: Totalidad e infinito. Ensayo sobre la exterioridad, Salamanca, Ediciones Sígueme, 1977, 47.

(3) J.P. Miranda: Marx y la Biblia, Salamanca, Ediciones Sigueme, 1975, 2. a ed., 115.

(4) Citado por J.P. Miranda: op. cit., 116. 
fratricida, sino que se volvió fratricida por su propia voluntad» (5). La amenaza de Génesis 2,17, no se cumple, no se produce la muerte al comer el fruto prohibido. Sin embargo, Génesis 4, 1-11 es inequívoco: la muerte entra en la historia por mano del hombre. En el capítulo tercero del Génesis Dios maldice a la serpiente y a la Tierra, pero no al hombre. Cain, en cambio, es el primer hombre al que Dios maldice.

«He ahi, pues, todo el sentido redaccional del Génesis que nos introduce a la historia del pueblo de Israel cuya misión será levantar la maldición del hombre que se pronunció en 4,11» (6).

En el Corán, el hombre aparece caracterizado, ya antes de su creación, como aquel ser capaz de derramar la sangre de sus semejantes:

"Y cuando tu Señor dijo a los ángeles: "voy a poner un sucesor en la Tierra". Dijeron: "¿vas a poner en ella a alguien que corrompa y derrame sangre...?" " (7).

Como en el Génesis, en el Corán el hombre es también arrojado del Paraíso, pero en el Corán se relaciona de una manera explícita este arrojamiento con la situación de enemistad entre los hombres, situación que aparece, por consiguiente, como nueva, distinta de la anterior, aunque de ésta nada se diga expresamente. El estar en el mundo conlleva ese estado de enemistad. Así lo tenemos dicho en esa aleya citada al principio: «iDescended! Seréis enemigos unos de otros», que parece pesar sobre los seres humanos como una maldición, y que en cierta manera recuerda la noción del «mal radical» de Kant.

En alguna ocasión se dice en el Corán que es Dios quien pone enemistad y odio entre los judíos (8), o entre los cristianos (9). En otras el creyente pide a Dios que no ponga odio en su corazón contra los que creen (10). El Demonio intenta suscitar odio y enemistad mediante el vino y el juego del maysir (11).

El sentido tan evidente de esta enemistad no lo es tanto, sin embargo, para la mayoría de los comentaristas coránicos (12) y por eso dedican éstos largas disquisiciones en las que tratan de precisar a quien puede referirse dicha enemistad, si a Adán con relación a Eva, o si a ambos con relación al Demonio o con la serpiente, etc. Como una opinión más, y sin insistir ni profundizar en ello, se cita en al-Tabari (13), y será repetido por posteriores comentaristas, que este «enemigos unos de otros» puede referirse a Adán, a Eva y a sus descendientes.

Ninguna duda, en cambio, manifiesta al-Zamajšarī sobre esta última opinión, ya que dice explícitamente:
(5) Ibid., 116.
(6) Ibid, 117
(7) C. 2,30 .
(8) C. 5,64 .
(8) C. 5,14 .
(10) C. 59,10 .
(11) C. 5,91 .

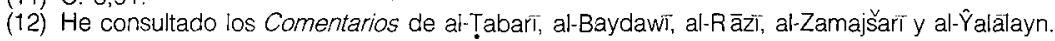
(13) En su Comentario a C. 2,36; 7,24 y 20,123. 
«La opinión correcta es que se habla a Adán y a Eva y se quiere referir con ello a ellos dos y a su descendencia, porque teniendo en cuenta que ambos son el principio del género humano y de su multiplicación, han sido puestos aquí como si se tratase de toda la humanidad» (14).

Esta situación de enemistad no tarda en dar sus frutos, cumpliéndose lo predicho por los ángeles, pues pronto el primer derramamiento de sangre humana tiene lugar, tal como nos es relatado en la versión coránica de Caín y Abel (15), que termina con la siguiente observación:

«Por esta razón, prescribimos a los Hijos de Israel que quien matara a una persona que no hubiera matado a nadie ni corrompido la Tierra, fuera como si hubiera matado a toda la Humanidad» (16).

En la Risālat al-gufrān (17) dedica 'Abū 'Alā' al-Ma'arrì dos versos a esta muerte de Abel a manos de Caín en los que subraya el cambio de estado que sobrevino a la humanidad con esta acción:

«Sufrieron un cambio los países y sus moradores y la faz de la Tierra se volvió polvorienta y fea.

Quedó desolado el campamento formado por los que habitaban la Tierra y partieron dejando abandonado en el polvo el rostro hermoso".

Este desolado paisaje humano no cree ya al-Ma'arrī que pueda cambiar nunca, según nos dice en sus Luzümiyyāt, en la número 26 (18), en donde, tras comparar a los hombres con el tiempo, en cuanto a su composición de luz y tinieblas, considera imposible una unión entre ellos, al descartar, por utópico, el símil de la convivencia de la liebre con el sacre. Implícitamente está sugiriendo, pues, que ésta es la situación del hombre.

Desde esta visión de la naturaleza humana, brota en la cultura árabe-islámica, como en la occidental, la idea del poder como un freno a esos instintos criminales, considerándolo como la única solución para hacer posible la vida humana, pese a los inconvenientes y problemas que a su vez pueda acarrear (19).

La verdadera superación, sin embargo, de este estado de enemistad y escisión es contemplada en el Corán no como una obra del hombre sino como una obra exclusivamente divina:

«... Recordad la gracia que Dios os dispensó cuando eráis enemigos: reconcilió vuestros corazones y por su gracia, os transformastéis en hermanos... (20).

... Él es Quien te ha fortalecido con Su auxilio y con los creyentes, cuyos corazones

(14) Cfr, en su Comentario a C. 2,36.

(15) C. 5, 27-32

(16) C. 5,32 .

(17) Ed. 'Ali Šalaq, Beirut, 1975, 171.

(18) Cfr. texto, traducción y comentario de varios autores bajo el significativo título de: «al-Macarri: Peace on Earth?», Journal of Arabic Literature, 4 (1973), 57-68

(19) Idea presente en numerosos autores de teoria política. Cfr. el estudio de M.J. Viguera: «El mundo islámico» en F. Vallespín, ed.: Historia de la teoría política. I, Madrid, Alianza Editorial, 1990, 325-369

(20) C. 3,103 
Él ha reconciliado. Tú, aunque hubieras gastado todo cuanto hay en la Tierra, no habrías sido capaz de reconciliar sus corazones. Dios, en cambio, los ha reconciliado...» (21).

Esta última aleya es citada por Ibn Jaldun en la Muqaddima (22) para mostrar que las belicosas tribus árabes sólo podían ser unificadas por obra de Dios en la religión islámica, asunto al que dedica varios capítulos haciendo ver la función de la religión en este sentido.

La culminación de esta obra divina de restauración de la fraternidad originaria, en la que quedarán superadas todas las divisiones de una manera total y definitiva, escatológica, sólo tendrá lugar con la vuelta al Paraíso:

«Los que temen a Dios estarán entre jardines y fuentes. "Entrad, en paz, seguros!". Extirparemos el rencor que quede en sus corazones. Serán como hermanos...» (23).

Sobre estas aleyas comenta al-Tabari una tradición de 'Ali que dice: «espero estar yo, 'Utmān, Talha y al-Zubayr entre éstos» (24), tradición que es luego repetida en posteriores comentaristas.

También Abū 'Alā' al-Ma'arrī en su citada Risālat al-gufrān aduce estas aleyas a propósito de varios gramáticos mutuamente enfrentados a los que ve juntos y hermanados en el Paraíso (25).

Una vez, pues, solucionados todos los posibles conflictos de esta vida y en este incomparable marco del Paraíso coránico resuena allí, en contraposición a los vaniloquios de este mundo, una sola palabra: paz, paz:

«No oirán alli vaniloquio ni incitación al pecado, sino una palabra: "iPaz! ¡Paz!"» (26).

(21) C. 8, 62-63.

(22) Cfr. Prolegomenes d'Ebn-Khaldoun, texte arabe par M. Quatremère, v. I, Paris, 1858, 284, trad. franc. de V. Monteil: Discours sur /histoire universelle (al-Muqaddima), Beirut, 1967, v. I, 310

(23) C. $15,45-47$. Cfr. con $7,43$.

(24) Se trata de enemigos entre si enfrentados en la lucha por el poder tras la muerte del Profeta. Véase sobre ello en Cl. Cahen: El Islam. I. Desde los origenes hasta el comienzo del Imperio Otomano, Madrid, 1972, 21-25.

(25) Cfr. ed. citada, 40.

(26) C. $56,25-26$. 